BJHS: Themes 2:151-168, 2017. C British Society for the History of Science 2017. This is an Open Access article, distributed under the terms of the Creative Commons Attribution-

NonCommercial-NoDerivatives licence (http://creativecommons.org/licenses/by-nc-nd/4.0/), which permits non-commercial re-use, distribution, and reproduction in any medium, provided the original work is unaltered and is properly cited. The written permission of Cambridge University Press must be obtained for commercial re-use or in order to create a derivative work.

doi:10.1017/bjt.2017.5 First published online 10 April 2017

\title{
Restor(y)ing the 'fierce green fire': animal agency, wolf conservation and environmental memory in Yellowstone National Park
}

\author{
KAREN R. JONES*
}

\begin{abstract}
This paper tracks human-animal entanglements through one particular species, Canis lupus, the wolf, with a view to exploring how this contested predator might be used to unpack normative assumptions about wildlife science, conservation practice and storytelling. The focus of attention here is on Yellowstone National Park and the century-long struggle to eradicate and then restore the wolf based on the shifting rubrics of science and environmental ethics. The 'wild heart' of North America and a centre of scientific and popular environmental mythology, Yellowstone presents a useful terrain (both material and contextual) in which to theorize the wolf as an environmental agent and explore its special provenance within an evolving narrative of ecological science. More specifically, the landmark story of restor(y)ation that played out in the national park serves to illuminate the complex web of temporality, narrative and memory that frames our configurations of animal agency. Wiped out in the late nineteenth and early twentieth centuries and ruminated on in the interwar period, the wolf was returned to ancestral haunts in the 1990s (to great fanfare) as a charismatic poster animal for environmental consciousness and a vital 'missing link' in the psychological and biotic fabric of the landscape. Ornamented with what conservationist Aldo Leopold famously called a 'fierce green fire', the wolf became a carrier animal for Yellowstone's environmental memory, transporting with it the fates of other threatened species and the promise of an enlightened Ecological Age. Beneath this teleological tale of expanding biological knowledge and ethical awakening lies a convoluted (and interesting) story that reveals the sinuous connections between the material and the imagined animal as well as the challenges and the complexities of reading non-human traces.
\end{abstract}

We reached the old wolf in time to watch a fierce green fire dying in her eyes. I realized then, and have known ever since, that there was something new to me in those eyes - something known only to her and to the mountain. I was young then, and full of trigger-itch; I thought that because fewer wolves meant more deer, that no wolves would mean hunters' paradise. But after seeing the green fire die, I sensed that neither the wolf nor the mountain agreed with such a view.

Aldo Leopold, 'Thinking like a mountain', 1944

A canonical moment in the history of modern ecological science, Aldo Leopold's encounter with the she-wolf took place in the Apache National Forest, Arizona, in 1909. As he later narrated in the seminal work 'Thinking like a mountain', the shared gaze with the

\footnotetext{
* School of History, University of Kent, Canterbury, Kent, UK. Email: k.r.jones@kent.ac.uk.
} 
wolf, his prey and, most specifically, the 'fierce green fire' dying in her eyes represented a formative encounter, convincing the young wildlife manager of the efficacy of preserving predatory animals and taking a view - an ecologically inflected longue durée - that considered species relationships on the basis of an ecocentric vantage. ${ }^{1}$ An iconic figure in the development of American environmental ethics, Leopold's life has been well documented by environmental historians and needs no further regurgitation here. ${ }^{2}$ What I want to draw attention to, though, is the importance of narrative, memory and inscription in his oft-quoted 'conversion' story. The point of starting here - on a dusty rimrock in the desert Southwest - is to note just how profoundly this episode shaped American environmental consciousness in subsequent years. 'Thinking like a mountain' was, as Gavin Van Horn points out, a 'foundational reference point' that combined science and ethics to argue that humans should relate to the biosphere as 'citizens' rather than as despoilers. ${ }^{3}$ It was, in the context of this article, fundamentally important for the meanings it inscribed on the wolf and the way the wolf was remembered. Imbued with a vivid and eternal 'fierce green fire', Canis lupus became a storied animal that communicated the environmental predicament of industrialism through its howl of 'wild defiant sorrow'. Translated into collective memory, Leopold's shared gaze with a shewolf thus became a kind of rhetorical crossing point for inter-species communication and environmental atonement, a moral fable of wilderness rehabilitation and human restitution. Such sentiments found their logical denouement in the restoration of wolves to Yellowstone in 1994-1996.

Environmental historian Donald Worster hails Leopold's paean in no uncertain terms: 'more than any other piece of writing, this work signalled the arrival of the age of ecology'. ${ }^{4}$ Pertinently, the case of the 'fierce green fire' also presents a useful introduction to the thorny problem of tracking the relationship between ecological science and animal protagonists that are undeniably present but also absent. For one thing, there are somewhat complicated (and particularly historical) issues of chronology and causality lurking beneath Leopold's story of ecological revelation. His moment of epiphany - a singular moment of realization - was not written up until 1944, thirty-five years on from the martyrdom of the she-wolf. In the meantime (and in common with a number of naturalresource managers of his generation), Leopold debated the value of predatory animals

1 Aldo Leopold, A Sand County Almanac, New York: Ballantine Books, 1966 (first published 1949), pp. 137-141.

2 For discussion of Leopold's life and emerging philosophy see Donald Worster, Nature's Economy: A History of Ecological Ideas, Cambridge: Cambridge University Press, 1994, pp. 258-291; Susan Flader, Thinking Like a Mountain: Aldo Leopold and the Evolution of an Ecological Attitude towards Deer, Wolves, and Forests, Madison: University of Wisconsin Press, 1994; Julianne Newton, Aldo Leopold's Odyssey, Washington, DC: Island Press, 2006; Curt Meine, Aldo Leopold: His Life and Work, Madison: University of Wisconsin Press, 2010; Thomas Dunlap, Saving America's Wildlife: Ecology and the American Mind, 1850-1990, Princeton, NJ: Princeton University Press, 1988, pp. 88-92; J. Baird Callicot, Companion to A Sand County Almanac: Interpretive and Critical Essays, Madison: University of Wisconsin Press, 1987.

3 Gavin Van Horn, 'Making of a wilderness icon: green fire, charismatic species and the changing status of wolves in the United States', in Aaron Gross and Anne Vallely (eds.), Animals and the Human Imagination, New York: Columbia University Press, 2012, pp. 203-237, 212.

4 Worster, op. cit. (2), p. 284. 
as part of a dynamic and circulating discourse within a professional community of wildlife biologists. It was, as biographer Curt Meine points out, 'hands-on' work with deer management in Wisconsin in the mid-1940s that fully crystallized his thinking on predator-prey dynamics. ${ }^{5}$ Accordingly, it seems reasonable to conclude that Leopold invoked the long-dead she-wolf as part of what Jon Coleman calls an 'allegory of enlightenment'. ${ }^{6}$ Novelist Graham Swift reminds us that man is a 'storytelling animal' and the choice of a narrative pathway allowed for the abstractions of ecological science to be popularly visualized. ${ }^{7}$ Set within an autobiographical frame, the wolf was a material subject, anchoring Leopold's change of attitude to a particular place and a particular moment. At the same time it was a spectral animal, a faded abstraction that conjured a sense of times past and regret for the demise of the 'wild things' that formerly roamed the American continent. The truth of Leopold's cognitive journey as ecological scientist may have been rather more drawn-out, but in his environmental memory it was Canis lupus that delivered a profound message. He writes, 'my own conviction on this score dates from the day I saw a wolf die': leaving us with an intriguing case of an animal agency that was ritually symbolic but posthumous and postponed. ${ }^{8}$

Equally significant, in the broader tale of wolf restor(y)ation there is a cacophonous refrain to be found in both scientific and popular quarters: what did ecological science do for the wolf? It saved it. In simple terms, the narrative goes something like this. We killed off the wolves out of irrationality and prejudice. The science of ecology (Leopold et al.) taught us about food chains, biotic pyramids and ecosystems. With this enlightened environmental knowledge in our possession, we returned the wolf to old haunts and restored 'nature's balance'. ${ }^{9}$ Aside from its rather hackneyed take on the unassailable objectivity of modern science and the comforting teleology of environmentalist conscience (humans as despoilers-saviours), there are problems here of anthropocentrism and value judgement. What wolves did (in terms of materialities and behaviour) largely stayed the same, but their trace was successively imprinted with a range of cultural meanings. This beastly reconfiguration reminds us of Erica Fudge's comment that animal history is more of a history of our attitudes towards other species, or, in wolf-specific terms, Barry Lopez's adage, 'in the wolf we have not so much an animal that we have always known as one that we have consistently imagined'. ${ }^{10}$ Such conclusions raise questions about how we 'read' animal agency, and,

5 Meine, op. cit. (2), p. 14.

6 Jon Coleman, Vicious: Wolves and Men in America, New Haven, CT: Yale University Press, 2004, p. 220.

7 Graham Swift, Waterland, New York: Poseidon, 1983, p. 53.

8 Leopold, op. cit. (1), p. 138.

9 The US Fish and Wildlife Service, for instance, asserted that 'after centuries of fantasy and superstition, wildlife research has yielded a new picture of the wolf'. US Fish and Wildlife Service, Northern Rocky Mountain Wolf Recovery Plan, Denver: USFWS, 1987, p. 10. For historical surveys that emphasize ecology as a critical aspect of changing attitudes see Dunlap, op. cit. (2); Rick McIntyre (ed.), War against the Wolf, Stillwater, MN: Voyageur Press, 1995; Bruce Hampton, The Great American Wolf, New York: Henry Holt, 1997.

10 Erica Fudge, 'A left-handed blow: writing the history of animals', in Nigel Rothfels (ed.), Representing Animals, Bloomington: Indiana University Press, 2002, pp. 3-18; Barry Lopez, Of Wolves and Men, New York: Touchstone Books, 1978, p. 204, original emphasis. 
as Zeb Tortorici put it, about the difference between incorporating other species into the histories we tell and locating them centre stage as historical actors. ${ }^{11}$ On this, recent work in animal studies offers useful guidance, having matured from its early (and often polemic) focus on giving the animal voice, rights and power into a sophisticated discourse in which the mechanics of agency are seen as complex and interconnected. For David Shaw, the idea of 'unities' presents a useful methodological framework for including human and non-human protagonists, while Chris Pearson charts a useful course in plotting canine agency in terms of 'doing-with-an-effect'. ${ }^{12}$ Most recently, Joshua Specht has argued that the 'triumph' of animal history renders the 'proving' of animal agency an obsolete paradigm and instead recommends 'mapping the varied economic, political, social and cultural contexts in which animals are embedded' ${ }^{13}$ This article builds on such scholarship in highlighting the active role of animals in the production of environmental networks and systems of knowledge while at the same time pointing to the importance of a narrative architecture that shaped how wolf traces were inscribed and preserved. As humans, scientists and historians, our stories come from 'being in the world' but also contain an interpretive impetus that constantly rewrites the terms of engagement with the non-human. ${ }^{14}$ As such, our collective readings of the 'fierce green fire' (much like Leopold's) referenced a wolf both material and spectral. By unpeeling the physical and imaginative layers to this inter-species encounter, we reveal the power (and the temporality) of storytelling as well as the possibility, as seen by Ryan Hediger, that 'nonhuman forms of agency can appear when we adjust our ways of perceiving it to particular scenarios - contexts - and to different forms of life'. ${ }^{15}$ With such methodological tangles in mind, a provocative point of departure thus might be not 'what did ecological science do for the wolf?' but 'what did the wolf do for ecological science?'

\section{The Yellowstone wolf: sighting, writing and removal}

Established in 1872 and spanning more than three thousand square miles of Rocky Mountain terrain, Yellowstone represents America's 'crown jewel' nature reserve and a keen locus of conservation thinking. The story of wolves in the park and the various inscriptions given to their 'fierce green fire' present a striking opportunity to track the history of a particular species, analyse how ecological science played out in context, and see the historical twists and turns of environmental memory in action. By putting 'science in its place', as David Livingstone recommends, we can acknowledge the

11 Zeb Tortorici, 'Animal archive stories: species anxieties in the Mexican National Archive', in Susan Nance (ed.), The Historical Animal, New York: Syracuse University Press, 2015, p. 86.

12 David Shaw, 'A way with animals', History and Theory (2013) 52(4), pp. 1-12, 8; Chris Pearson, 'Dogs, history, and agency', History and Theory (2013) 52(4), pp. 128-145, 133.

13 Joshua Specht, 'Animal history after its triumph: unexpected animals, evolutionary approaches and the animal lens', History Compass (2016) 14, pp. 326-336, 332.

14 Tim Ingold, The Perception of the Environment, London: Routledge, 2000, p. 75.

15 Ryan Hediger, 'Crossing over: (dis)ability, contingent agency and death in the marginal genre work of Templen Grandin and Jim Harrison', in Susan McFarland and Ryan Hediger (eds.), Animals and Agency: An Interdisciplinary Exploration, Leiden: Brill, 2009, pp. 321-340. 
importance of spatial context in the history of science and, most importantly, excavate the fragments of animal history in a discreet setting. ${ }^{16}$ Most usefully in this regard, Yellowstone has been the subject of intense scrutiny: a place where wolves have been catalogued, chased and choreographed for more than a century. Animal tracks are there to be found in myriad locations: in the landscape itself, in scientific data, in policy documents, in warden reports and even in the gift shop with its books, T-shirts and souvenir trinkets. This expansive documentary trail goes some way to ameliorate the fundamental problem of writing animal history - text - and makes the Yellowstone wolf an ideal candidate for exploring what Tortorici calls the 'historical, historicized and archived/ archiveable animal'. ${ }^{17}$ From the generalized animals (the 'marauding packs' of early records) to documented individuals (Wolf 10, Wolf 42) from the reintroduction period, wolf sign has been collected, written up, preserved and necessarily displaced, mediated through eyewitness testimonial and contemporary points of scientific and cultural reference. Linda Nash's advice on jettisoning a model of animal agency contingent on finding 'intentionality and purposeful action' is useful here in mitigating the fact that wolves don't transcribe their own versions of history (though Ingold asserts they have one), as are Vinciane Despret's thoughts on agencement (or inter-agency): a world in which animals appear as 'secret agents' with the capacity to incite and inspire amid a dizzying flow of connected forces. ${ }^{18}$ Finally, in approaching Yellowstone's amassed wolf sign, it is worth bearing in mind that animal traces in the archive - physical, textual and metaphorical - carry with them a disruptive power, a capacity to collapse boundaries and destabilize the terms of environmental memory. As Tortorici notes, the archive is a 'biopolitical and necropolitical space that challenges us to be fully conscious of how animal life supports and complicates the archive stories we tell'. ${ }^{19}$

The archival trail in Yellowstone's early years reveals a site under configuration, a new schematic of land governance and an abstract concept of conservation that required fleshing out. Set aside as a 'public park or pleasuring-ground for the benefit and enjoyment of the people', Yellowstone was sited as a democratic space in which the American nation could revel in the geological monumentalism of the Far West. ${ }^{20}$ An operational mandate to maintain the park in a 'natural condition' left much room for manoeuvre (early tourists eagerly plugged Old Faithful with rubbish to spice up its hydrological performance) and provided momentum for the removal of anything seen as detrimental to preservationist visions as understood by early managers. From the outset, staff records reveal Canis lupus as a pariah animal (although interestingly, the fact that the wolf

16 David Livingstone, Putting Science in Its Place: Geographies of Scientific Knowledge, Chicago: The University of Chicago Press, 2003, pp. 1-13.

17 Tortorici, op. cit. (11), p. 86.

18 Linda Nash, 'The agency of Nature and the nature of agency', Environmental History (2001) 10, pp. 6769, 68; Ingold, op. cit. (14), p. 61; Vinciane Despret, 'From secret agents to interagency', History and Theory (2013) 52(4), pp. 29-44, 38, 40, 44.

19 Tortorici, op. cit. (11), p. 86.

20 'An Act to set apart a certain tract of land lying near the head-waters of the Yellowstone Rivers as a public park', US Statutes at Large, vol. 17, Chapter 24, pp. 32-33, reprinted in L.C. Crampton, Early Histories of Yellowstone National Park and Its Relation to National Park Policies, Washington, DC: US Government Printing Office, 1932, pp. 76-77. 
was regarded as a beastly influence to be driven from Yellowstone's confines ensured its regular mention in the archival record). In his annual report for 1877, Yellowstone's second park superintendent Philetus Norris called for the protection of the 'wild game of all kinds' and the imposition of severe penalties for those who killed grazing animals. ${ }^{21}$ Poachers came in for criticism, and, as consumers of animals deemed appropriate members of the park community, so did Canis lupus. Norris put things starkly in a section of his 1880 report called 'Animals of the park': elk were 'beautiful, interesting and valuable' and wolves 'large' and 'ferocious'.22 Such views reflected broader normative attitudes to wildlife in a period in which predators seemed to have little redeeming value beyond what price they might fetch as bounty or as fur bearers. More than anything else, this inscription of the wolf as a 'black-hearted criminal' reflected what Ronald Wauer and William Supernaught called a 'biological morality' that ranked animals by their eating habits. ${ }^{23}$ Wolves ate deer and elk, animals that local hunters and park tourists wanted to nurture. They also came under fire from local stock raisers, fearful of predators wandering outside the parks and depredating cattle and sheep. As S.W. McClure put it in an article for Country Gentleman (c.1914), 'is there a single reason for allowing these predatory animals to live? Certainly not. They do not perform a solitary service of value to mankind'. ${ }^{24}$

Chroniclers in later years largely attributed this anti-wolf stance to prejudice, fear and irrationality. Barry Lopez called the destruction of America's wolves an 'American pogrom', the product of a medieval mentality that read animals in terms of demonic trace, combined with a theriophobically inflected manifest destiny and the pioneer's pathological need to control at least one aspect of frontier life. ${ }^{25}$ As Jon Coleman explains in the significantly titled Vicious: Wolves and Men in America, the wolf was relentlessly extirpated from ancestral haunts, tortured and abused in 'spasms of terror that capped lifetimes of anxiety'. ${ }^{26}$ However, that was only part of the explanation. As Tortorici reminds us, readings of the archival animal are contingent on a presentist

21 P.W. Norris, 'Report upon the Yellowstone National Park to the Secretary of the Interior for the Year 1877’, p. 12, in Yellowstone National Park Reports, 1877-1900, Bancroft Library, University of California, Berkeley, CA.

22 'Annual report of the superintendent of Yellowstone to the Secretary of the Interior for the year 1880', pp. 38-42, in Yellowstone National Park Reports, 1877-1900, Bancroft Library, University of California, Berkeley, CA.

23 Lisa Mighetto, Wild Animals and American Environmental Ethics, Tucson: University of Arizona Press, 1991, p. 78; Ronald Wauer and William Supernaught, 'Wildlife management in the national parks: a historical perspective', National Parks (1983) 57, pp. 12-16, 13.

24 S.W. McClure, 'The wolf at the stockman's door', Country Gentleman, c.1914, reprinted in US Senate, Congressional Record, 25 February 1914, pp. 4575-4576. For histories of Yellowstone see Aubrey Haines's two-volume classic, The Yellowstone Story, Niwot: University Press of Colorado, 1996. James Pritchard, Preserving Yellowstone's Natural Conditions, Lincoln: University of Nebraska Press, 1999; and Richard West Sellars, Preserving Nature in the National Parks, New Haven, CT: Yale University Press, 1997, cover wildlife management issues, while for the wolf specifically see Karen R. Jones, Wolf Mountains: A History of Wolves along the Great Divide, Calgary: University of Calgary Press, 2002, pp. 15-58; and Paul Schullery (ed.), The Yellowstone Wolf: A Guide and Sourcebook, Worland, WY: High Plains Publishing, 1996.

25 Lopez, op. cit. (10), p. 167.

26 Coleman, op. cit. (6), p. 213. 
lens and infused with a sense of 'species anxiety'. ${ }^{27}$ As such, the modern witnesses to the archived animal focused on the vitriol and the venom, expressing and affirming an ethical distance between how we view wolves now and how we did then that championed science as its principal guide (much like Leopold's 'fierce green fire' memory). Such an emphasis serves to obscure the fact that early park managers also used science as a key tool of legitimation to put flesh on the bones of their professional authority. That the wolf was a cruel and rapacious killer was presented as an entirely factual position, and, as warden records illuminate, rangers passed up no opportunity to kill any wolf they came across in order to exterminate the 'threat' to Yellowstone. Patrols became more systematic through the 1890s (including the use of poison) and especially with the creation of a federal architecture (the National Park Service was founded in 1916). Armed not only with guns, dogs and bait but also with arguments about wolf 'damage' and disturbances to the 'balance of nature', extermination became a glorious refrain and a scientifically ordained policy mandate. Accordingly, the documentary trace on wolf removal depicts an environmental 'good' not to be concealed in moderated language but proclaimed using the rhetoric of efficiency and cleansing ('control' and 'cleaning out'). ${ }^{28}$ Articulated in language befitting a military engagement, the pursuit of Yellowstone's wolves (along with tallies of kills) was laid out in monthly warden records through the late 1920s. In the 1914-1926 period, 136 animals were taken, eighty of which were pups. ${ }^{29}$ This archival inventory - in which wolves were written into the historical record as fleeting but apparently malevolent beings - allows the reconstruction of the last fragments of wolf presence in Yellowstone, of sightings, writings and the removal of wolf sign. Two animals killed by Ranger Henry Anderson in October 1922 at the confluence of the Pelican and Raven rivers were made into taxidermy mounts and put on permanent display at the Albright Visitor Centre, a keen indication not only of the historical gravitas of the removal but also of firm connections between science and exhibition culture. ${ }^{30}$

Today, the eradication of the wolf from Yellowstone typically inspires comment on westward conquest and the deleterious impacts of modern industrialism on the biosphere. But what does the documentary record tell us about wolf agency, conservation and narrative? A picture unfolds of a complex human-animal entanglement where separating the material from the imagined animal proves difficult. Leading Biological Survey biologist Vernon Bailey presents a useful summation of period wildlife management philosophy in his Animal Life of Yellowstone National Park (1930). Wolves were 'destructive', 'troublesome' and 'powerful' animals of which 'constant care' needed to be taken

27 Tortorici, op. cit. (11), p. 93.

28 'Debate on funding predator control program', US Senate, Congressional Record, 25 February 1914, pp. 4572-4583; Albert Day and Almer Nelson, 'Wild life conservation and control in Wyoming under the leadership of the United States Biological Survey' (1928), reprinted in McIntyre, op. cit. (9), p. 193; Lloyd Brett, Report of the Acting Superintendent of the Yellowstone National Park to the Secretary of the Interior for the Year 1915, Washington, DC: Government Printing Office, 1915, p. 22.

29 John Weaver, 'The wolves of Yellowstone, history, ecology and status', in Natural Resources Report No. 14, National Park Service, Washington, DC: Government Printing Office, 1978, pp. 1-38.

30 Vernon Bailey, Animal Life of Yellowstone National Park, Baltimore: Charles C. Thomas, 1930, p. 135. 
to stop them taking hold. The use of emotional adjectives proved the mediated nature of wildlife science, while descriptions of physical resilience, appetite for game, reproductive capacity and robust pack structure were clothed in a cautionary language that projected on the wolf an almost supernatural ability to hunt game and evade capture. At first glance, such assumptions smack of Lopez's 'imaginary wolf' (the frontier whispers of pioneer storytelling, the still tentative hold of settler communities over western space, and the propaganda machinations of federal agencies keen to justify their own existence), but there is an attention to wolf activity and close observation in this reportage that deserves further examination. For all their misplaced readings of the meaning of wolf sign, the first generation of wildlife managers in Yellowstone did, at least in part, assimilate their views of Canis lupus from time in the field. The disjuncture, it seemed, lay in how that animal activity was inscribed. Bailey, for instance, justified his findings on the basis of examining a kill site on Slough Creek, tracks on Fox Creek, and pack presence at Pelican Creek that signalled three critical convergences, (a) wolf scat containing a predominance of elk hair, (b) circling ravens and (c) a dearth of elk calves. The maturation of wildlife science and an ecological perspective stressing complex biotic causality qualified his hypothesis ('wolves and game can not be successfully maintained on the same range'), but two things are worth elucidating. ${ }^{31}$ First, Bailey's recourse to a located scientific method (what Robert Kohler calls 'an intimate residential knowledge of a particular place that gradually became more cosmopolitan and scientific') that showed the beginnings of a professional wildlife management founded on a direct engagement with the materialities of wildlife; and second, the importance of the wolf as an actor leaving an evidentiary trail. ${ }^{32}$ On the latter point, it is worth remembering that basic biological goals - survival, sustenance, security and procreation - rendered the wolf an important environmental agent in the park, what Paul Taylor might call 'a teleological (goal-oriented) center of life, pursuing its own good in its own unique way'. ${ }^{33}$ More pertinently, it also made it an ecological rival. Engaged in what Coleman calls 'transcendence', the attempt to 'pass down genetic, cultural, and material legacies to their offspring', the prerogatives of Yellowstone's wolf communities collided with new human visions for the park as a place of abundant game, scenic spectacle and public resort. ${ }^{34}$ Evidence of wolf presence - whether demonstrated by the material witness of a paw print or conceived in more ethereal (but omnipresent) terms - thus took on huge significance. One might reasonably argue that the campaign to eradicate the wolf from Yellowstone was fundamentally rooted in a renunciation of wolf agency, not in the sense that it was ignored (in fact, quite the opposite) but in the way that predation was imprinted with morbid consequence. BBS hunter Stanley Young, for one,

31 Bailey, op. cit. (30), pp. 134-137.

32 Robert Kohler, All Creatures: Naturalists, Collectors, and Biodiversity, 1850-1950, Princeton, NJ: Princeton University Press, 2013, p. 187.

33 Paul Taylor, Respect for Nature: A Theory of Environmental Ethics, Princeton, NJ: Princeton University Press, 1986, p. 45.

34 Coleman, op. cit. (6), pp. 230-231. 
anticipated a much brighter future for 'America's greatest quadruped' if it would only change its dietary habits. ${ }^{35}$

\section{Tracking the fierce green fire: ecology and the wolf's absent presence}

A sustainable wolf population may have disappeared from Yellowstone's landscape in the 1920s but that did not stop Canis lupus exerting a decisive influence over the shape of wildlife management over the next half-century. This story of animal presence in absentia provokes interesting questions about the importance of rarity in refining human attitudes to wild predators as well as the variegated possibilities for an agency that incorporates the spectral or symbolic animal. Literature scholar S.K. Robisch posits that the disappearance of the wolf from much of the contiguous USA in this period leaves us with a wolf of 'disproportionately imaginative' design. ${ }^{36}$ For Leopold, and indeed, for the collective environmental memory of Yellowstone, Canis lupus was rendered ever more potent (and poignant) by the scarcity of actual wolf materialities in the park. This allowed for two developments: a growing interest in the inventory of vestigial pack sign and gathering remorse about the removal of the 'wild defiance' of the wolf howl from Yellowstone's quarters, and a concern for the moral and material impact of its removal. The power of the wolf - its 'fierce green fire' was enshrined in a mode of absent presence. As cultural theorist Elisa Adami points out, 'Absences are not just what there is not, but rather what was there and now is not any longer, or what should be there and yet is not. ${ }^{37}$ Meanwhile, in writing the positive story of wolf restor(y)ation, attention focused on who was 'speaking' for the wolf in this period and the rise of ecological science as redeemer. As Mike Link and Kate Crowley put it in Following the Pack: The World of Wolf Research, it became the task of the professional ecologist to develop and dispel popular prejudice and facilitate entry into 'the world of the wolf'. ${ }^{38}$

The interwar period proved a critical era in the formulation of animal ecology as a discipline and saw heated debate in the wildlife management community about the nature and direction of their vocation. Leading protagonists outlined emerging tenets such as food chains, ecosystems, succession theory and the relationship between biocoenesis (animal communities) and the biotope (environment) in such works as Frederic Clements's Research Methods in Ecology (1905), Charles Christopher Adams's Guide to the Study of Animal Ecology (1913) and Charles Elton's Animal Ecology (1927). ${ }^{39}$

35 Stanley Young quoted in Worster, op. cit. (2), pp. 277-278.

36 S.K. Robisch, Wolves and the Wolf Myth in American Literature, Reno: University of Nevada Press, 2009, p. 25.

37 Elisa Adami, 'Mnemoscape: in the presence of absence', available at www.mnemoscape.org/in-thepresence-of-absence, accessed 28 November 2016, original emphasis.

38 Mike Link and Kate Mike Crowley, Following the Pack: The World of Wolf Research, Stillwater, MN: Voyageur Press, 1994, pp. 8, 16-17.

39 For the development of ecology as science see Frank Golley, A History of the Ecosystem Concept in Ecology, New Haven, CT: Yale University Press, 1993; Joel Hagen, An Entangled Bank: The Origins of Ecosystem Ecology, New York: Rutgers University Press, 1992; Mark Barrow, Nature's Ghosts: Confronting Extinction from the Age of Jefferson to the Age of Ecology, Chicago: The University of 
These years also saw the establishment of professional networks and organizations, including the Ecological Society of America (1915) and the American Society of Mammalogists (1919), which provided a forum in which animal biologists answered Adams's complaint that ecology was 'a science with its facts out of all proportion to their organization or integration'. ${ }^{40}$ Significantly, the archival record in Yellowstone adds to this picture in interesting ways, presenting a muddled landscape of animal sign, science and sentiment in which a fading trail of wolf activity and the intellectual mechanics of ecological science conspired to create a new narrative of wildlife management. Park wolves weighed into this issue in formative ways as America's foremost wilderness reserve became a key site of debate and an outdoor laboratory to test ecology 'in action' (especially in terms of ideas of adaptation and the role of predatory animals in trophic dynamics).

In a speech that many of his forebears would have regarded as deeply heretical, exranger and chief naturalist Milton P. Skinner stood before the 6th Annual Meeting of the American Society of Mammalogists in 1924 to issue a rousing defence of the value of predatory animals. Later published in the Roosevelt Wild Life Bulletin as 'The predatory and fur-bearing animals of Yellowstone National Park', Skinner began by talking about historical antipathy towards carnivores, as well as practices of killing in the park based on an imperative to swell numbers of other, desirable animals. Carried out 'without a thorough investigation', this policy had not seen that 'we need these predatory and fur bearing animals alive and living their normal lives'. They were, he argued a 'valuable possession' under threat of extinction and held a rightful place in parklands where a full complement of native species should be preserved in a state 'approaching primitive, natural conditions'. Where the first generation of conservation managers in Yellowstone had purposely excluded the wolf, now it was welcomed by virtue of its indigeneity and 'scientific, educational and recreational' value. Significantly, in voicing his critique, Skinner did not attack the hallowed ground of scientific objectivity but instead chose to point out that past policy had been 'unscientific' in design and 'careless' in prosecution (critics, incidentally, lambasted such arguments as 'emotional' and the 'radical utterances of fool conservationists'). In future, he argued, due care and attention needed to be placed on 'careful, minute investigations' based on the idea that 'every animal is keenly interesting - especially ones as highly developed and diversified as the predatory animals are'. ${ }^{41}$ This latter point was particularly important - from being outcasts in the landscape due to their dietary habits, wolves now vaulted to prominence as lead actors in a functioning ecological community. The 'big bad wolf' was recast as 'big good wolf' in a reversed polarity of environmental agency. Moreover, as Skinner pointed out, the dynamics of predation meant that wolves tended to take sick or diseased prey, a revised valuation that saw wolf agency (hunting) as making a worthy contribution to

Chicago Press, 2009; Gregg Mitman, State of Nature: Ecology, Community, and American Social Thought, 1900-1950, Chicago: The University of Chicago Press, 1992; Sharon Kingsland, The Evolution of American Ecology, Baltimore: Johns Hopkins University Press, 2008.

40 Charles Christopher Adams, Guide to the Study of Animal Ecology, New York: Macmillan, 1913, p. vi.

41 Milton P. Skinner, 'The predatory and fur-bearing animals of Yellowstone National Park', Roosevelt Wild Life Bulletin (1927) 4(2), pp. 185-186. 
evolutionary ecology and ungulate health. Such postulations were radical and important contributions to an evolving theoretical discourse (what Charles Elton called a 'scientific natural history') as well as presenting a new formulation of the rules of human-wolf encounter in Yellowstone. ${ }^{42}$ What Leopold later eulogized as the 'fierce green fire' was in the process of being reconfigured. Meanwhile, in comments that rehearsed a position still hotly debated among animal studies scholars, wildlife managers contended that the only way to apprehend the 'real' animal was by field observation. In a declaration of purpose that foregrounded empiricism and laid the groundwork for ecology's transit from science to environmental agenda, Skinner saw the responsibilities of wildlife biology as twofold: unlocking the 'truth' about predator-prey dynamics and forging a responsible policy of engagement with the natural world.

Skinner's pro-wolf manifesto outlined three key aspects of new attitudes that were crystallizing in Yellowstone: first, of the equal citizenship due to park predators based on their 'positive' ecological agency; second, of the cultural and scientific value of a place preserved in a 'nearly original state'; and last, of the value of the parks as refuges for species facing extinction elsewhere. Such ideas were fleshed out in other landmark reports, notably George Wright, Joseph Dixon and Ben Thompson's Fauna of the National Parks (1933), and confirmed in a graduated series of revised environmental policy dictates. ${ }^{43}$ Wholesale predator control was wound down after 1925, the use of steel traps prohibited in 1928 and poison banned in 1931. New directives in 1933 installed predatory animals as 'special charges' and emphasized the importance of maintaining the parks in a 'primitive state' and of non-interference 'with biotic relationships'. Predation became 'normal utilization' based on what one 1939 policy document read as the triumph of 'impartial scientific data' over 'ancestral prejudice'. ${ }^{44}$ On the ground, meanwhile, wildlife managers were conjuring with the implications of the wolf's absent presence in their new readings of ecological health and wilderness mythology. Naturalist Edmund Heller tracked through Yellowstone in 1924, 'saddened ... not to hear a wolf howl' or spy a pack in 'full cry after their hoofed quarry', while a rare sighting inspired enthusiastic welcome from Marguerite Arnold, whose 1937 article for Nature magazine pre-empted Leopold in describing a 'red letter day' crouched in the snowy timberline in receipt of an 'uncomprehending stare' from a large black wolf. ${ }^{45}$ These archival tracks paid heed to the fluid hermeneutic boundaries of what constituted 'good' science, the raw power of animal encounter, and the shifting ground of environmental memory in Yellowstone.

42 Charles Elton, Animal Ecology, New York: Macmillan, 1927, p. 1.

43 George Wright and Ben Thompson, Fauna of the National Parks of the United States (Fauna Series No 2), Washington, DC: National Park Service, 1934, p. 15.

44 'Discussion of service predator control policy', 'Chronological record of general correspondence relating to predator control' and 'Condensed chronology of predator control policy', all enclosed with 'Memo from Victor Cahalane, Acting Chief, Wildlife Division to Dr Carl Russell', 22 March 1939, Box N17, Folder 719, Yellowstone National Park Research Library, Mammoth Hot Springs, Yellowstone National Park, Wyoming.

45 Edmund Heller, 'The big game animals of Yellowstone National Park', Roosevelt Wild Life Bulletin (1925) 2(4), p. 430; Marguerite Arnold, 'Yellowstone wolves', Nature Magazine (1937) 30(2), pp. 111-112. 
A recurring character in Yellowstone's historical record, Canis lupus appeared first as extant villain and then as vanishing hero in a case of mistaken identity worthy of the most salacious dime novel. That the wolf was now missing added further weight to its scientific and cultural inscription, as Skinner pointed out: 'once destroyed we cannot bring it back'. ${ }^{46}$ Reports from other significant lupine sites, meanwhile, only served to amplify the significance of the wolf's absent presence. At the Kaibab plateau on the Grand Canyon's North Rim (where Leopold had recommended predator control measures in 1920), the irruption of mule deer populations, habitat degradation, overbrowsing and the starvation of up to 70,000 of the herd in 1930 provided a cautionary tale about the environmental consequences of a 'wolf-less' landscape. ${ }^{47}$ Research from Sigurd Olson in Minnesota and Adolph Murie in Alaska - areas with buoyant wolf populations - instead revelled in landscapes in 'equilibrium', home to complex pack communities and resilient prey species. ${ }^{48} \mathrm{~A}$ chronicle of den activity, trackways, howls, hunts and social life, Murie's Wolves of Mount McKinley (1944) presents ample evidence of the 'archived animal' (the document of two years in the field) as well as the narrative architecture of an 'ecological wolf' under construction. ${ }^{49}$ Related in testimonial form, Murie's treatise - just like Leopold's - provided a vivid example of the descriptive power of science-as-story as well as reinserting the biological animal into the equation as an actor (but not scriptwriter) in its own inscription. As Garry Marvin reminds us, our representations of animals may be conjured in a cognitive landscape, but somewhere along the trail those ideas come from a 'direct experience of - or a direct encounter with - an embodied, living animal'. ${ }^{50}$ As such, the story of wolf rehabilitation pays heed to Despret's ideas of agencement: animals inciting and inspiring human commentary in a tangled web of agency, narrative and inscription.

\section{Wolves return to Yellowstone: an ecology of hope and fear}

In The Wolves of North America (1944), Stanley Young and Edward Goldman, once keen advocates of predator control, openly agreed that there were places in the United States where the wolf might live unperturbed. ${ }^{51}$ In his review of their book, Aldo Leopold put forward the suggestion that national parks, and Yellowstone in particular, presented obvious places for 'restocking'.52 A half-century later, in the winter of 19941995, Canis lupus was welcomed back to Yellowstone National Park as part of a federal

46 Skinner, op. cit. (41), p. 185.

47 On the Kaibab episode see Christian Young, In the Absence of Predators, Lincoln: University of Nebraska Press, 2002.

48 Sigurd Olson, 'A study in predatory relationships with particular reference to the wolf', Scientific Monthly (1938) 46, pp. 323-324.

49 Adolph Murie, The Wolves of Mount McKinley (Fauna Series No 5), Washington, DC: National Park Service, 1944, pp. 143, 9-60.

50 Garry Marvin, 'Seeing, looking, watching: observing non-human animals', Society \& Animals (2005) 13, pp. 1-11, 1.

51 Stanley Young and Edward Goldman, The Wolves of North America, Part 1: Their History, Life Habits, Economic Status and Control, New York: Dover, 1944, p. 385.

52 Aldo Leopold, 'Review of The Wolves of North America', Journal of Forestry (1944) 42, pp. $928-929$. 
reintroduction programme costing $\$ 6$ million. Returning the 'fierce green fire' to America's premier nature reserve represented many things - a wholesale reappraisal of the wolf based on its biotic value (carried forth in the post-1945 period by a new generation of wolf biologists including Durward Allen, Douglas Pimlott, Rolf Petersen and L. David Mech); a burgeoning environmental consciousness keen to atone for what proponents saw as the crimes of modern industrialism against nature; an array of partromantic, part-testimonial literature on Canis lupus from Lois Crisler, Farley Mowat and other writers that canonized the wolf as a charismatic emblem of the sacred wild; and a policy framework that provided bureaucratic sanction for the restoration of extirpated species, notably the advisory report chaired by A. Starker Leopold (Aldo's son) in 1963 which called for the preservation of national parks as 'vignettes of primitive America', the Endangered Species Act of 1973 and the 1987 Northern Rocky Mountain Wolf Recovery Plan. Significant in each of these was the logic of absent presence, the idea that Yellowstone was somehow 'unnatural' without Canis lupus roaming its confines. As Adami notes, the necessarily relational quality of presence and absence encourages a sense of 'temporal fluctuation or immoral omission' when someone or something is no longer there. ${ }^{53}$ Leopold's eulogy to the she-wolf had talked of regretful killing and ethical responsibility towards the natural world. A post-1945 environmentalist vernacular added redress and restoration to that list. Some went further still, deploying the idea of 'free, wild animals with green fire' to speak not only for the necessary return of the wolf but for a need to rewild the human soul. ${ }^{54}$

Twenty years in the making, the paper trail associated with wolf reintroduction saw Canis lupus confirm its long-held position as an animal with a commanding imprint on the archival record in Yellowstone. This plethora of data - compilations of historic populations and sightings, environmental-impact reports, modelling scenarios and carefully constructed management plans - paid heed to the maturation of wildlife management as a discipline, the involvement of multi-agency stakeholders and the cultural capital invested in bringing back a keystone species missing from the park's biotic complement. A landmark in restoration ecology and a signal of the emotive purchase of wilderness as environmental mantra, the wolf's restoration narrative traded in the idea of a four-legged deus ex machina who would restore healthy predator-prey dynamics and pump life back into the 'wild heart' of North America. A rousing endorsement of the assumed power of wolf agency (principally by hunting) and the efficacy of modern wildlife science, focus was placed on doing right by Yellowstone's enabling legislation restoring 'natural conditions' - and the importance of scientific monitoring and oversight by a cadre of professional biologists. Classified as 'experimental, non-essential populations', donor animals were chosen from carefully selected target sites in Canada and transported to Yellowstone, where they were treated to veterinary checks and vaccinations, dusted for parasites, given ear tags and transponders and placed in three acclimation pens in the Lamar valley. After eight weeks of eating frozen elk carcasses delivered

53 Adami, op. cit. (37).

54 Susan Zakin, Coyotes and Town Dogs: Earthfirst! and the Environmental Movement, Tucson: University of Arizona Press, 1993, p. 198. 
by rangers, chasing ravens, howling and playing with bones, the gates were opened and the grand experiment in restoring lupine tracks was under way.

Wolves may have been the poster animals for a rewilded landscape, but their movements were subject to intimate surveillance. Milton Skinner and other ecologists had called for meticulous field studies in the years of absent presence, and Yellowstone now became a prime field site for wolf analysis. Assumptions about empirical observation and critical distance continued to infer a firm physical and professional boundary between wolf and researcher, but, as Anita Guerrini points out, 'ecological science can also be as invasive and manipulative as other types of animal research'. ${ }^{55}$ Roaming a three-thousand-square-mile reserve, the newly formed Soda Butte, Crystal Creek and Rosebud packs were not exactly 'lab rats' but their movements were under scrutiny. Technology became a key tool in tracking animal trace, particularly in the radio collars worn by each animal, which set up an intriguing juxtaposition of America's most iconic wild predators dressed in the garb of domestic dogs and followed by radio telemetry across what Etienne Benson calls a 'wired wilderness'. ${ }^{56}$ Meanwhile, as Canis lupus wandered, howled and chewed its way across the park landscape, a new chapter in Yellowstone's environmental memory was catalogued for historical record and aired publicly through witness statements and such publications as Yellowstone Science. A signal of the allure of restored canine presence, the park duly became a locus for enthusiasts (colloquially known as 'wolf paparazzi') who diligently chronicled news of sightings, den activity and inter-pack engagements using Internet sites. Camped out in the Lamar valley with notebooks and spotting scopes, these various 'wolf watchers' in the field highlighted an intellectual lineage between natural history, ecological science and modern environmental ethics that had evolved over the span of a century. The gravitas placed on the Yellowstone scheme, meanwhile, laid added emphasis on the commitment of wolf sign to posterity, and, accordingly, saw the crafting of another layer of narrative inscription. In this most recent restor(y)ation - the era of restored presence - the elevation of the 'celebrity wolf' was a particularly important phenomenon. A focus on biography had been the feature of wolf chronicles before (see Leopold's she-wolf or the story of Roger Caras's Custer Wolf) and reflected a broader human prerogative to apprehend another species in personal (if not anthropocentric) terms. As Guerrini points out, 'in the case of the wolf, the individual was not quite subsumed to the system'. ${ }^{57}$ In the grand theatre of Yellowstone, the 'celebrity wolf' found plenty of room to roam, the once pariah animal given heroic mantle and special provenance. Observed as animals who 'made history', individual wolves were given a sort of lupine personhood, historicized and preserved as archival subjects. ${ }^{58}$ In

55 Anita Guerrini, 'Animals and ecological science', in Linda Kalof (ed.), The Oxford Handbook of Animal Studies, available at www.oxfordhandbooks.com/view/10.1093/oxfordhb/9780199927142.001.0001/ oxfordhb-9780199927142-e-25, accessed 5 December 2016, p. 6.

56 Etienne Benson, Wired Wilderness: Technologies of Tracking and the Making of Modern Wildife, Baltimore: Johns Hopkins University Press, 2010.

57 Guerrini, op. cit. (55), p. 8.

58 For chronicles of the wolf's return by eyewitnesses and/or those involved see Thomas McNamee, The Return of the Wolf to Yellowstone, New York: Henry Holt, 1997; Michael Phillips and Douglas Smith, 
Decade of the Wolf (2006) the broader narrative of an 'ecology of hope' was made manifest in the storied rendition of lupine lives (Wolf 42, the 'Cinderella Wolf', catapulted from one of the pack to dominant female in the Druid Peak Pack), tragic montages (the shooting of Wolf 10 outside Red Lodge, Montana by local Chad McKittrick) and moments of triumph (the formation of the Leopold Pack from Wolf 7 of the Rose Creek Pack and Wolf 2 of the Crystal Creek). ${ }^{59}$ T-shirts, coffee-table books and even personalized number plates (WOLF 42) demonstrated the imprint of these 'ambassador wolves' as a cultural phenomenon and the potency of storytelling as a way of communicating wildlife encounter.

What the wolves did collectively, meanwhile, painted a picture of a dynamic landscape that confounded the simulations of where the packs might settle and what their impact on the ecosystem might be. As such, restored wolf presence disrupted the accepted wisdoms of ecological science and advanced theoretical developments in a 'New Ecology' that increasingly saw ecosystems as places of flux. As of 2002, there were 216 wolves in Yellowstone, spread across twenty-eight packs, half of which claimed territory entirely in the park. Most areas of suitable wolf habitat had been reclaimed. The speed with which Canis lupus re-established territory attested to its resilience, the availability of prey species and an integrated federal management plan which took great trouble to involve regional constituencies. Wolves, it turned out, didn't den where the experts thought they would and few had predicted the impact of the wolf's return on its smaller canine cousin, the coyote, whose populations saw a sharp decline in the 1995-1998 period. Also significant were the apparent ecological consequences of wolf reintroduction on other species and habitat: the return of lupine trace seemingly triggering a trophic cascade that resonated through the biota. Such findings corroborated emerging work in ecological science that talked not about Leopold's or Murie's 'equilibrium' but a 'quilt-like pattern' of recovery, succession and disturbance. ${ }^{60}$ The northern-range elk herd (which had grown from a low point of four thousand at the end of culling in the 1960s to some seventeen thousand animals by 1995) had declined rapidly before stabilizing at between four thousand and seven thousand animals in the 2007-2012 period. Also important was the impact of predation on ungulate range and behaviour. Amounting to what one biologist dubbed 'an ecology of fear', elk had become more

The Wolves of Yellowstone, Stillwater, MN: Voyageur Press, 1996; Jim Yuskavitch, In Wolf Country: The Power and Politics of Wolf Reintroduction, Guilford: Lyons Press, 2015; Carter Niemeyer, Wolf Land, Boise: Bottlefly Press, 2016; Cat Urbigkit, Yellowstone Wolves, Blacksburg: McDonald \& Woodward, 2008; Hank Fischer, Wolf Wars, Helena: Falcon Press, 1995; Thomas McNamee, The Killing of Wolf Number Ten, Westport: Prospecta Press, 2014.

59 Douglas Smith and Gary Ferguson, Decade of the Wolf: Returning the Wild to Yellowstone, Guilford: Lyons Press, 2006.

60 On the 'New Ecology' see Daniel Botkin, Discordant Harmonies: A New Ecology for the 21st Century, Oxford: Oxford University Press, 1990. For the impact of the wolf's return on the Yellowstone ecosystem see Douglas W. Smith, Rolf O. Peterson and Douglas B. Houston, 'Yellowstone after wolves', Bioscience (2003) 53, pp. 330-340; William J. Ripple and Robert L. Beschta, 'Trophic cascades in Yellowstone: the first fifteen years after wolf reintroduction', Biological Conservation (2012) 145, pp. 205-213; Marion Hourdequin, 'Ecological restoration, continuity and change: negotiating history and meaning in layered landscapes', in Marion Hourdequin and David G. Havlick (eds), Restoring Layered Landscapes: History, Ecology, Culture, Oxford: Oxford University Press, 2016, pp. 13-33, 15. 
mobile and flighty, favouring open ground where they could see wolves at a distance and avoiding dense cover at riverbanks. ${ }^{61}$ These years also saw resurgent cottonwood, aspen and willow habitat, more songbirds and a spike in the beaver population. Beetles and ravens prospered from wolf carrion and bears enjoyed berries in greater abundance. According to Yellowstone scientist Nathan Varley, 'reintroducing the wolves into Yellowstone was like dropping a pebble into a pond that has not been disturbed for more than 60 years. The ripples will travel far into the future' ${ }^{62}$

Such findings provided a striking case for the importance of taking animal agency seriously but also raised notable challenges of how to 'read' non-human traces. At face value at least, the return of the wolf appeared to rejuvenate the entire ecosystem, confirming Leopold's vantage as to the command of the predator over a region's biotic health. The New York Times eagerly proclaimed that the hunting habits of wolves had changed the park's 'ecological balance'. ${ }^{63}$ Others, however, were rather were more sanguine. Yes, the reintroduction of a keystone species had sent a 'ripple' through the bioregion, but teasing out the categorical impact of one species from a tangled mass of human-non-human and non-human-non-human encounters was not a simple task, especially in the light of other variables such as climate change, hydrology and human hunting. As Arthur Middleton put it, the Yellowstone experiment showed that animals can surprise even the most experienced scientific minds ('we now know that elk are tougher, and Yellowstone more complex, than we gave them credit for'), but simply recasting wolves as prodigal heroes established a (potentially dangerous) new mythology (or, more accurately, rehashed an old one) and distracted people from other pressing issues facing the park, from pine tree fungal infestation to gas drilling. ${ }^{64}$ Leading canine biologist L. David Mech asked, 'Is science in danger of sanctifying the wolf?' while Yellowstone project leader Doug Smith pointed out that 'the danger we perceive is that all changes to the system, now and in the future, will be attributed solely to the restoration of the wolf'. ${ }^{65}$ If the swirling accolades around Canis lupus attested to an ecological fancy founded on science and sentiment, then the conclusions of the 'alpha' wolf biologists were equally historically consistent in looking to scientific objectivity for guidance. It was, they argued, the task of science to 'clarify' the view on the ground and provide an accurate picture. At the same time, however, the subtle inflections of ecology as ethical philosophy infused wildlife-management-speak by century's end. As project leader Michael Phillips pointed out, 'the world is vastly different through the eyes of a wolf ... and we have to respect that. They're not here to be pets. They're here because

61 Corey Binns, 'Yellowstone wolves reintroduce "ecology of fear”, Live Science, 27 July 2007, available at www.livescience.com/4554-yellowstone-wolves-reintroduce-ecology-fear.html, accessed 4 December 2016.

62 Nathan Varley, 'Total impact', Wolf Tracker (1997) 1, pp. 15-17.

63 Jim Robbins, 'Hunting habits of wolves change ecological balance in Yellowstone', New York Times, 18 October 1995.

64 Arthur Middleton, 'Is the wolf a real American hero?', New York Times, 9 March 2014, available at www.nytimes.com/2014/03/10/opinion/is-the-wolf-a-real-american-hero.html?_r=0, accessed 3 December 2016.

65 L. David Mech, 'Is science in danger of sanctifying the wolf?', Biological Conservation (2012) 150, pp. 143-149; Smith, Peterson and Houston, op. cit. (60), p. 339. 
it's the right thing to do'.66 An editorial in Nature entitled 'An elegant chaos', too, favoured more of a reflective slant on the inevitably mediated (and long history of) scientific work on wolves and pointed to the importance of passion in understanding our attachment to wild places and the critters therein:

Scientists like to impose structure and order on chaos, and ecologists are no different ... Ecological complexity, which may seem like an impenetrable thicket of nuance, is also a source of much of our pleasure in nature. If ecosystems all worked in the same way, they would lose much of their mystery, their surprise and their beauty. ${ }^{67}$

In the long restor(y)ation of Yellowstone's wolves, the temporality of scientific paradigms and their abiding relationship with imagination and memory were clearly evident.

\section{Unwanted, absent and restored presence: three acts of wolf restor(y)ation}

Tracked through various reconfigurations, the story of Yellowstone's 'fierce green fire' reveals a complex history of encounter, inscription and preservation. If the first act of restor(y)ation was one of persecution and the second of rehabilitation, then the third act spoke of ritual restitution. Each revealed the entwined contours of wildlife science and wildlife behaviour, and the narrative threads that inevitably shape our deciphering of wolf trace. Dorothee Brantz writes that 'luckily an element of surprise and unpredictability persists whenever we look at animals and especially when they look back at us' ${ }^{68}$ A brisk trek through the history of Yellowstone's wolves corroborates her thinking. A tale that has often been told around the wolf rather than of it, histories of ecological science have typically centred on the worlds of professional expertise and theoretical discourse. By thinking more seriously about how questions of animal agency, narrative and temporality weighed into this equation, however, the picture is not only productively embellished but also, in some instances, reframed. David Livingstone reminds us that 'scientists make science, but they do not do so entirely as they choose' in his plea for consideration of place as a vital aspect of understanding how science is 'made'. ${ }^{69}$ A premier outdoor laboratory and centre of wolf research, Yellowstone presents a valuable case study in this epistemological direction as well as highlighting the usefulness of writing histories that acknowledge the entangled relations of humans and non-humans and the sinuous connections between the material and imagined animal. Through periods of unwanted, absent and restored presence, Yellowstone's wolves were imprinted with meaning, communicated in story and used as carriers for environmental memory. Hence, when wildlife biologist Ed Bangs lamented that 'wolves and their management have almost nothing to do with reality' he made a point more profound than noting the challenges of a public-facing science. ${ }^{70}$ In Yellowstone, just as on Leopold's dusty rimrock, the 'fierce green fire' presented a wolf both material and spectral: a distant

66 Phillips quoted in Michael Milstein, Wolf Return to Yellowstone, Billings: Billings Gazette, 1995, p. 86. 67 'An elegant chaos', Nature (13 March 2014) 507, p. 139.

68 Dorothee Brantz (ed.), Beastly Natures: Animals, Humans, and the Study of History, Charlottesville: University of Virginia Press, 2010, p. 6.

69 Livingstone, op. cit. (16), pp. 13-14.

70 Ed Bangs quoted in McIntyre, op. cit. (9), p. 397. 
168 Karen R. Jones

body with an eternal gaze, endlessly elusive yet constantly referenced. Such complexities show the opportunities rather than the pitfalls of excavating wolf sign - what Benson calls 'material-semiotic remnants' - if we think in terms of Despret's agencement. ${ }^{71}$ Yellowstone's history clearly shows the imprint of Homo sapiens on the landscape, but, equally, in what we might call a site of Brett Walker's 'shared intimacy', there are plenty of other 'tracks [and] trails' embedded in this story. ${ }^{72}$ In the flesh and in the archive, the animals are there: the trick is how we go about reading their traces.

71 Etienne Benson, 'Animal writes: historiography, disciplinarity and the animal trace', in Linda Kalof and Georgina Montgomery (eds.), Making Animal Meaning, East Lansing: Michigan State University Press, 2011, p. 3.

72 Brett Walker, 'Animals and the intimacy of history', History and Theory (2013) 52(4), pp. 45-67, 67. 